\title{
Prion proteins in subpopulations of white blood cells from patients with sporadic Creutzfeldt-Jakob disease
}

\author{
Ed M Choi ${ }^{1, *}$, Michael D Geschwind ${ }^{2,3}$, Camille Deering ${ }^{1}$, Kristen Pomeroy ${ }^{1}$, Amy Kuo ${ }^{1}$, Bruce L Miller ${ }^{1,2,3}$, \\ Jiri G Safar ${ }^{1,3, \dagger}$ and Stanley B Prusiner ${ }^{1,3}$
}

Recent cases of prion transmission in humans following transfusions using blood donated by patients with asymptomatic variant Creutzfeldt-Jakob disease (CJD) implicate the presence of prion infectivity in peripheral blood. In this study, we examined the levels of the normal, cellular prion protein $\left(\operatorname{PrP}^{\mathrm{C}}\right)$, and the disease-causing isoform $\left(\operatorname{PrP}{ }^{\mathrm{Sc}}\right)$ in subpopulations of circulating white blood cells (WBCs) from patients with sporadic (s) CJD, age-matched neurological controls and healthy donors. Though widely distributed, the highest levels of $\operatorname{PrP}^{C}$ were found in a subpopulation of $\mathrm{T}$ lymphocytes: $\sim 12000 \mathrm{PrP}^{\mathrm{C}}$ molecules were found per $\mathrm{CD}^{+}{ }^{+} \mathrm{CD}$ 5 $\mathrm{RA}^{-} \mathrm{CD}^{-} \mathrm{L}^{-}$effector memory $\mathrm{T}$ helper cell. Although platelets expressed low levels of $\operatorname{PrP}^{C}$ on their surface, their high abundance in circulation resulted in the majority of $\operatorname{PrP}{ }^{C}$ being platelet associated. Using quantitative fluorescence-activated cell sorting analysis, we found that neither WBC composition nor the amount of cell-surface $\operatorname{PrP}^{C}$ molecules was altered in patients with SCJD. Eight different WBC fraction types from the peripheral blood of patients with SCJD were assessed for PrP ${ }^{S c}$. We were unable to find any evidence for $\mathrm{PrP}^{\mathrm{Sc}}$ in purified granulocytes, monocytes, B cells, $\mathrm{CD} 4^{+} \mathrm{T}$ cells, $\mathrm{CD} 8^{+} \mathrm{T}$ cells, natural killer cells, nonclassical $\gamma \delta \mathrm{T}$ cells, or platelets. If human WBCs harbor prion infectivity in patients with SCJD, then the levels are likely to be low.

Laboratory Investigation (2009) 89, 624-635; doi:10.1038/labinvest.2009.30; published online 11 May 2009

KEYWORDS: assay; blood; Creutzfeldt-Jakob disease; detection; prion; WBC

Prions cause a group of fatal, rapidly progressing neurodegenerative diseases, including Creutzfeldt-Jakob disease (CJD) in humans. Sporadic (s) CJD accounts for approximately $80 \%$ of all CJD cases worldwide. ${ }^{1}$ In the late 1990 s, an outbreak of a new form of CJD, termed variant (v) CJD, occurred in Europe, predominantly in the UK. Since then, nearly 200 cases of vCJD have been identified worldwide and studies indicate that vCJD is caused by consumption of contaminated animal products from cattle with bovine spongiform encephalopathy. ${ }^{2}$

All prion diseases are caused by the accumulation of an aberrantly folded isoform, denoted $\mathrm{PrP}^{\mathrm{Sc}}$, of the prion protein $(\operatorname{PrP})$. Encoded by the PRNP gene in humans, $\operatorname{PrP}$ is a glycosylated membrane protein distributed predominantly on neurons. PrP was first isolated from the brains of hamsters inoculated with an adapted strain of sheep prions. ${ }^{3,4}$ Later, genomic sequencing of genetic CJD cases revealed nonconservative mutations in the PRNP gene of affected family members. ${ }^{5,6}$ With a basic amino acid composition and an unstructured $\mathrm{N}$ terminus, PrP can adopt at least two metastable conformations: (1) native, $\alpha$-helix-rich cellular prion protein $\left(\operatorname{PrP}^{\mathrm{C}}\right)$ and (2) disease-causing, $\beta$-sheet-rich $\operatorname{PrP}^{\mathrm{Sc}}$. The latter is self-perpetuating, and continues to recruit and convert more $\operatorname{PrP}^{\mathrm{C}}$ molecules into $\mathrm{PrP}^{\mathrm{Sc}}$ oligomers, which can assemble into amyloid plaques in the brain. Events that catalyze the refolding of $\operatorname{PrP}^{\mathrm{C}}$ into $\operatorname{PrP}^{\mathrm{Sc}}$ have eluded molecular characterization thus far, but the conversion is often accompanied by decreased solubility as well as increased resistance to protease digestion. ${ }^{8}$

Although prion infectivity is most readily isolated from the CNS, it can also be found widely distributed among extraneuronal tissues, especially in patients with vCJD. ${ }^{9-11}$ This distribution in part is due to the ubiquitous expression pattern of $\operatorname{PrP}^{\mathrm{C}}$ that is required for prion infection. In blood, for instance, $\operatorname{PrP}^{C}$ is mainly found in the soluble plasma fraction, but is also expressed on different white blood cells

\footnotetext{
${ }^{1}$ Institute for Neurodegenerative Diseases, University of California, San Francisco, CA, USA; ${ }^{2}$ Memory and Aging Center, University of California, San Francisco, CA, USA and ${ }^{3}$ Department of Neurology, University of California, San Francisco, CA, USA

Correspondence: Dr SB Prusiner, Institute for Neurodegenerative Diseases, University of California, 513 Parnassus Avenue, HSE-774, San Francisco, CA 94143-0518, USA. E-mail: stanley@ind.ucsf.edu

*Current address: The Stowers Institute for Medical Research, 1000 E 50th Street, Kansas City, MO 64110, USA

${ }^{\dagger}$ Current address: National Prion Disease Surveillance Center, Case Western University, 2085 Adelbert Road, Cleveland, OH 44106, USA
} Received 7 March 2009; accepted 9 March 2009; published online 11 May 2009 
(WBCs) as well as platelets. ${ }^{12}$ The expression of $\operatorname{PrP}^{\mathrm{C}}$ on follicular dendritic cells in secondary lymphoid organs is required for prion transmission, especially during peripheral routes of inoculation. ${ }^{13-15}$ Experimental inoculations and subsequent passages in animal models, such as mice, hamsters, sheep, elk, and macaques, have shown variable levels of prion infectivity in tissues, such as spleen and muscle, as well as in plasma and buffy coat WBC. ${ }^{16}$ It has been estimated that the level of infectivity in blood is $<100$ infectious units (IU) per ml in mice inoculated with mouse-adapted human prions, magnitudes lower than that of the brain. ${ }^{17,18}$

Recently, several cases of prion transmissions have been reported in the UK. These patients contracted CJD years after having received non-leukodepleted blood products from asymptomatic donors who were later diagnosed with vCJD. ${ }^{19-22}$ Although the causal linkage between blood transfusion or factor VIII administration and these CJD cases cannot be proven experimentally, these incidences have ignited debates over the presence of prion infectivity in blood and highlighted the urgent need to develop an antemortem blood test to identify presymptomatic CJD cases and to safeguard the blood supply. Several biological markers have been proposed, but the presence of $\operatorname{PrP}^{\mathrm{Sc}}$ remains the only reliable and specific indicator of prion diseases. Some progress has been made in the detection of prions in experimentally infected hamsters by protein misfolding cyclic amplification, but its efficacy for human use has yet to be proven. ${ }^{23}$ Recently, some of us (JGS, CD, MDG, BLM, SBP) found that $\operatorname{PrP}^{\mathrm{Sc}}$ in the brains of patients with sCJD binds to very-low-density and low-density lipoproteins (LDLs) in plasma. ${ }^{24}$ Prions did not bind to high-density lipoproteins or other plasma components.

In this study, we established that effector memory (EM) T cells, of all the WBCs in circulation, express the highest number of surface $\operatorname{PrP}^{C}$ per cell. Patients with sCJD, neurological controls, and healthy donors were found to have similar levels of surface $\operatorname{PrP}^{\mathrm{C}}$ on their WBC. We have isolated granulocytes, monocytes, B cells, $\mathrm{CD} 4^{+} \mathrm{T}$ cells, $\mathrm{CD} 8{ }^{+} \mathrm{T}$ cells, natural killer (NK) cells, nonclassical $\gamma \delta \mathrm{T}$ cells, and platelets from fresh whole blood samples from patients with sCJD, neurological controls, and healthy donors, using magnets or fluorescence-activated cell sorting (FACS). Even after we optimized a conformation-dependent immunoassay (CDI) ${ }^{25-27}$ we were unable to detect $\mathrm{PrP}^{\mathrm{Sc}}$ in any of the WBC fractions. Our results show that if prions are present in the blood of patients with SCJD, they are present at low levels.

\section{MATERIALS AND METHODS \\ Patients and Blood Samples}

Blood samples were obtained from 24 patients diagnosed with definite or probable sCJD. The diagnosis of definite sCJD was only made after immunohistological verification at autopsy. The cohort had a median age of 65 years and a median age of disease onset of 64. All 24 patients had a known genotype: the frequencies of the PRNP codon 129 polymorphism were $54 \% \mathrm{M} / \mathrm{M}, 33 \% \mathrm{M} / \mathrm{V}$, and $13 \% \mathrm{~V} / \mathrm{V}$ (Table 1). Genetic prion diseases were ruled out by genomic DNA sequencing, and postmortem analysis was performed on 19 of 24 deceased patients to confirm the diagnosis. For neurological controls, 27 age-matched subjects were identified. The majority $(63 \%)$ of these controls were diagnosed with Alzheimer's disease and the remaining patients suffered from other neurological disorders, including progressive supranuclear palsy, corticobasal degeneration, frontal lobe dementia, dementia with Lewy bodies, and paraneoplastic limbic encephalitis. Whole blood samples from more than 30 anonymous healthy donors were obtained from the Stanford Blood Center. From each patient, $30-500 \mathrm{ml}$ of blood was drawn and stored at $-4^{\circ} \mathrm{C}$ until processed.

\section{Blood Sample Processing}

Fresh whole blood samples were processed within $24 \mathrm{~h}$ of being drawn. Due to the scale of the WBC isolation procedures, we divided our blood sorting experiments into three phases, each tailored to maximize the yield of a different set of WBC. In Phase I, which was used to isolate granulocytes, monocytes, $\mathrm{CD}^{+}{ }^{+} \mathrm{T}$ cells, and $\mathrm{B}$ cells, whole blood samples were centrifuged at low speed $\left(162 \mathrm{~g}, 10 \mathrm{~min}, 4^{\circ} \mathrm{C}\right)$. The supernatant fractions were collected and centrifuged at higher speed $\left(365 \mathrm{~g}, 5 \mathrm{~min}, 4^{\circ} \mathrm{C}\right)$. The pellets were collected, resuspended in PBS with $10 \mathrm{mM}$ EDTA, and the centrifugation repeated. The final pellet was resuspended in a FACS Lysing Solution (BD) to remove red blood cells, followed by a washing step in PBS with $10 \mathrm{mM}$ EDTA. In Phases II and III, which were used to isolate B cells, CD8 ${ }^{+}$T cells, NK cells, $\gamma \delta$ $\mathrm{T}$ cells, and platelets, whole blood samples were first concentrated by centrifugation at $4^{\circ} \mathrm{C}$ for $10 \mathrm{~min}$ at $365 \mathrm{~g}$. The cell pellets were then reconstituted to twice the original blood

Table 1 Demographics of the cohorts of patients with SCJD and neurological controls used in this study

\begin{tabular}{|c|c|c|c|c|c|c|c|}
\hline Groups & Patient composition & $\begin{array}{l}\text { Median age } \\
\text { (range) }\end{array}$ & $\begin{array}{l}\text { Median age of } \\
\text { onset (range) }\end{array}$ & Female/Male & $\mathrm{M} / \mathrm{M}$ & $\mathrm{M} / \mathrm{V}$ & V/V \\
\hline $\operatorname{sCJD}(n=24)$ & 79\% Pathology confirmed & $65(49-79)$ & $64(49-78)$ & $10 / 14$ & 13 & 8 & 3 \\
\hline Neurological controls $(n=27)$ & 63\% Probable Alzheimer's disease & $66(49-83)$ & $61(46-78)$ & $17 / 10$ & 14 & 5 & 3 \\
\hline
\end{tabular}


volume in PBS with $10 \mathrm{M}$ EDTA, and layered over a $60 \%$ isotonic Percoll gradient (GE Healthcare) for buffy coat isolation. Specimens for cell sorting were resuspended in PBS supplemented with $1 \%$ fetal calf serum, $0.25 \mathrm{U} / \mathrm{ml}$ DNaseI (Roche), and Complete protease inhibitors (Roche) before antibody staining.

\section{Flow Cytometry and Fluorescence Microscopy}

All FACS was performed on the FACS Aria (BD) contained within a custom-made hood in our biosafety level 3 (BSL3) facility. Aerosol release from the Aria was monitored using fluorescent Glo Germ particles (Glo Germ, UT, USA) ${ }^{28}$ Data were acquired using the FACS DiVa (BD) software and analyzed with the FlowJo software. WBC enumeration was performed using TruCOUNT tubes (BD) in combination with monoclonal antibodies against WBC markers $\mathrm{CD} 3$, CD4, CD8a, CD19, CD16, CD41, CD56, CD61, V 82 TCR (BD). For fluorescent labeling of surface PrP molecules, we used monoclonal mouse antibodies 6H4 (Prionics) or 3F4, in conjunction with anti-mouse secondary antibodies conjugated to FITC (BD), PE (BD), or Alexa Fluor 594 (Molecular Probes). For isotype control, mouse IgG1 and IgG2a antibodies were used as the primary antibody. Alternatively, a panel of humanized anti-PrP Fab fragments, including D18, P, EST123, and EST149, ${ }^{29}$ was used with anti-human Fab secondary antibodies (Jackson Laboratory).

For quantitative measurement of surface $\operatorname{PrP}$ molecules, Percoll-processed buffy coats were stained first with $2.5 \mu \mathrm{g} / \mathrm{ml}$ of $6 \mathrm{H} 4$ or mouse IgG1 isotype control antibody for $1 \mathrm{~h}$ at $4^{\circ} \mathrm{C}$. At this saturating concentration, the $6 \mathrm{H} 4$ and control staining exhibited the greatest difference in their resulting fluorescence intensities. These samples were then stained with anti-mouse FITC antibody for $45 \mathrm{~min}$ at $4{ }^{\circ} \mathrm{C}$ and with a series of QIFIKIT calibration beads (Dako) bearing knownamount, antibody-binding sites. In the final staining step, WBCs were labeled with different cell-surface markers, as listed above. For comparison of naive $v s$ memory $\mathrm{CD} 4^{+} \mathrm{T}$ cell, six-color staining was performed using CD3-PE-Cy7, CD4-APC-Cy7, CD62L-PerCP-Cy5.5, CD45RA-APC, CD27$\mathrm{PE}$, and $6 \mathrm{H} 4$. Quantitative flow cytometry on platelets was performed on magnetically isolated platelet fractions (see below) and gated according to size and granularity. Each time quantitative FACS analysis was performed, a standard curve was generated by the aforementioned calibration beads, correlating fluorescence intensity with the number of bound antibodies. The number of $\operatorname{PrP}$ molecules per cell was extrapolated from this calibration, upon subtracting the background fluorescence (isotype control) from the total fluorescence (6H4). All determinations of surface $\operatorname{PrP}$ molecules were performed in duplicate.

For fluorescence microscopy of peripheral NK cells, circulating $\mathrm{CD}^{-}$lymphocytes were first isolated from lysed whole blood using FACS and then CD3-depleted with Dynal beads. These cells were labeled with the anti-PrP 3F4 antibody and Alexa Fluor 594-conjugated anti-mouse secondary antibody (Molecular Probes), followed by anti-CD56 (NCAM) FITC (BD).

\section{FACS Sorting of WBCs}

Blood samples were FACS sorted using the FACS Aria (BD) under a custom four-way-sort mode to ensure maximal separation efficiency as well as purity. Routine decontamination was performed using $1 \mathrm{M} \mathrm{NaOH}$ to avoid potential crossover contamination between samples. Because the $\mathrm{BD}$ FACS Aria can only isolate a maximum of four cell populations at a time, we isolated different sets of circulating WBCs in two phases. A third phase to isolate platelets was performed using magnetic-activated cell sorting (MACS; see below).

For Phase I isolation, WBCs were stained with CD4-PE and CD19-APC to isolate granulocytes (forward scatter high, side scatter (SSC) high, $\mathrm{CD}^{-}, \mathrm{CD}^{-} 9^{-}$), monocytes (SSC high, $\mathrm{CD} 4^{+}, \mathrm{CD} 19^{-}$), $\mathrm{CD} 4^{+} \mathrm{T}$ cells (SSC low, $\mathrm{CD} 4^{++}$, $\mathrm{CD} 19^{-}$), and $\mathrm{B}$ cells (SSC low, $\left.\mathrm{CD} 19^{+}, \mathrm{CD} 4^{-}\right)$. For isolation of WBC subpopulations in Phase II, buffy coats were stained with CD3-PE-Cy5, CD8-APC-Cy7, CD19-APC, CD56-FITC, and $\mathrm{V} \delta 2 \mathrm{TCR}-\mathrm{PE}$, to enable concomitant five-color sorting of $\mathrm{CD}^{+}{ }^{+} \mathrm{T}$ cells $\left(\mathrm{CD} 3^{+}, \mathrm{CD}^{+}, \mathrm{V} \delta 2 \mathrm{TCR}^{-}, \mathrm{CD} 19^{-}\right), \mathrm{NK}$ cells $\left(\mathrm{CD}^{-}, \mathrm{CD}^{+}, \mathrm{CD}^{+} 6^{+}, \mathrm{V} \delta 2 \mathrm{TCR}^{-}\right)$, nonclassical $\gamma \delta \mathrm{T}$ cells $\left(\mathrm{CD}^{+}, \mathrm{CD} 8^{-}, \mathrm{V} \delta 2 \mathrm{TCR}^{+}, \mathrm{CD} 19^{-}\right)$, and $\mathrm{B}$ cells $\left(\mathrm{CD} 19^{+}\right.$, $\mathrm{CD}^{-}, \mathrm{CD} 56^{-}, \mathrm{V} \delta 2 \mathrm{TCR}^{-}$). The purity of all post-sort samples was confirmed by FACS before the cells were centrifuged at $365 \mathrm{~g}$ for $30 \mathrm{~min}$, and frozen in aliquots.

\section{Magnetic Sorting of Platelets}

For isolation of platelets, Percoll-processed buffy coats were stained with anti-CD61 antibody-coated MACS microbeads (Miltenyi Biotec), before fractionation by the AutoMACS machine (Miltenyi Biotec). To eliminate cross-contamination, we decontaminated the AutoMACS using 10\% bleach between samples and all AutoMACS LS columns (Miltenyi Biotec) were limited to single use.

\section{Conformation-Dependent Immunoassay}

The CDI was performed as described previously, ${ }^{27}$ with several modifications. First, purified WBCs were resuspended in a PBS (pH 7.4), containing 2\% (w/v) Sarkosyl, $5 \mathrm{mM} \varepsilon^{-}$ aminocaproic acid (6-aminohexanoic acid; Sigma), $1 \mathrm{mM}$ $\mathrm{MgCl}_{2}, 1 \%(\mathrm{w} / \mathrm{v})$ brain homogenate from $\operatorname{Prnp}^{0 / 0}$ mice, $0.1 \mathrm{mM}$ phenylmethylsulfonyl fluoride (PMSF; Sigma), and $1 \mu \mathrm{g} / \mathrm{ml}$ each of aprotinin and leupeptin (Sigma). The cells were homogenized by one 75-s cycle in a reciprocal homogenizer Mini-BeadBeater-8 (BioSpec Products Inc., OH, USA) and treated with $50 \mathrm{IU} / \mathrm{ml}$ of benzonase for $30 \mathrm{~min}$ at $37^{\circ} \mathrm{C}$. $\mathrm{PrP}^{\mathrm{Sc}}$ was precipitated with $0.32 \%(\mathrm{w} / \mathrm{v})$ phosphotungstic acid for $1 \mathrm{~h}$ at $37^{\circ} \mathrm{C}$, then centrifuged at $14000 \mathrm{~g}$ for $30 \mathrm{~min}$. The pellet was resuspended in $100 \mu \mathrm{l}$ of PBS (pH 7.4), containing $0.2 \%$ Sarkosyl, $0.1 \mathrm{mM}$ PMSF, and $1 \mu \mathrm{g} / \mathrm{ml}$ each of aprotinin and leupeptin, then split into two aliquots. One aliquot, denoted $\mathrm{D}$ for denatured, was denatured at $80^{\circ} \mathrm{C}$ in 
$4 \mathrm{M}$ guanidinium $\mathrm{HCl}(\mathrm{GdnHCl})$; the other aliquot was left undenatured and designated $\mathrm{N}$ for native. Aliquots of $20 \mu \mathrm{l}$ from each fraction were directly loaded into wells of white Greiner strip plates (Greiner Bio-One) prefilled with $200 \mu \mathrm{l}$ of assay buffer (Wallac) and coated previously with MAR1 anti$\operatorname{PrP}$ capture antibody. ${ }^{30}$ The captured $\operatorname{PrP}$ was detected by a europium-conjugated anti-PrP $\mathrm{mAb} 3 \mathrm{~F}^{31}$ or recombinant antibody fragment (recFab) $\mathrm{P}^{26}$ The amount of $\operatorname{PrP}^{\mathrm{Sc}}$ in a given WBC sample is directly proportional to the difference in the fluorescence signals (measured in counts per minute) from denatured and native samples, or $(\mathrm{D}-\mathrm{N})$.

The preparation and purification of $\operatorname{recHuPrP}(90-231)$ used as a calibrant in the CDI were described previously. ${ }^{24,32}$ The purity of recHuPrP(90-231) was assessed by mass spectrometry. The molecular mass for $\operatorname{recHuPrP}(90-231)$ was $16059 \mathrm{Da}$, as expected. The protein concentration was determined by UV spectroscopy using the predicted molar extinction coefficient of $24420 \mathrm{M}^{-1}$. The purified protein was dissolved in $4 \mathrm{M} \mathrm{GdnHCl}$ and $50 \%$ StabilCoat (SurModics, Eden Prairie, MN, USA), and stored at $-80^{\circ} \mathrm{C}$.

The concentration of total $\operatorname{PrP}^{\mathrm{C}}$ in fractionated WBC was calculated from the CDI signal of nondenatured cell lysate. Proteinase K treatment of WBC samples decreased the signal/ noise ratio and was therefore excluded from this protocol.

\section{Statistical Analysis}

Dot plots were produced using the KaleidaGraph software and mean values shown as horizontal lines. In comparing different patient groups, $P$-values were calculated using type 2 Student's $t$-test.

\section{RESULTS}

\section{PrPC Expression on Human WBCs}

$\operatorname{PrP}^{\mathrm{C}}$ expression is required for prion replication. ${ }^{33,34}$ Previously, surface $\operatorname{PrP}^{\mathrm{C}}$ was detected on all the major subsets of circulating WBCs in humans, albeit at levels much lower than those found in the CNS. ${ }^{12,35}$ Because the expression pattern of $\operatorname{PrP}^{\mathrm{C}}$ may reflect the capacity of different WBCs to support prion replication, we performed detailed FACS analyses to identify all of the WBC subpopulations in fresh human peripheral blood. $\mathrm{PrP}^{\mathrm{C}}$ was found on the surfaces of granulocytes, monocytes, $\mathrm{CD} 4^{+} \mathrm{T}$ cells, $\mathrm{CD} 8^{+} \mathrm{T}$ cells, nonclassical $\gamma \delta \mathrm{T}$ cells, $\mathrm{CD} 19^{+} \mathrm{B}$ cells, $\mathrm{CD} 56^{+} \mathrm{CD}^{-} \mathrm{NK}$ cells, and $\mathrm{CD} 41^{+} \mathrm{CD} 1^{+}$platelets (Figure 1a; data not shown).

On the surface of neurons, $\operatorname{PrP}^{\mathrm{C}}$ was found to interact with the neural cell adhesion molecule (N-CAM) and subsequently activate $\mathrm{p} 59^{\mathrm{fyn}}$-mediated signaling. ${ }^{36-39}$ Because NK cells coexpress $\mathrm{PrP}^{\mathrm{C}}$ and N-CAM, we performed immunostaining and fluorescence microscopy to visualize their expression pattern. Circulating $\mathrm{CD}^{-} \mathrm{CD}^{-}$lymphocytes were purified by FACS and MACS sorting. The NK cells in this fraction were stained first with anti-PrP 3F4 antibody and Alexa Fluor 594-labeled anti-mouse secondary antibody, and then with anti-CD56 (N-CAM) FITC. On unpolarized cells, $\operatorname{PrP}^{\mathrm{C}}$ (red) assumes a punctate appearance, evenly distributed over much of the surface (Figure 1b, top panels). N-CAM (green) does not localize with $\mathrm{PrP}^{\mathrm{C}}$ in unpolarized cells. However, on polarized $\mathrm{NK}$ cells in the same fraction, $\operatorname{PrP}^{\mathrm{C}}$ and $\mathrm{N}$-CAM colocalized at one end of the cell, possibly due to redistribution of lipid rafts and the associated GPI-anchored proteins (Figure 1b, bottom panels).

\section{Factors Affecting PrP ${ }^{C}$ Expression in WBCs}

The $\mathrm{N}$ terminus of $\mathrm{PrP}^{\mathrm{C}}$ in hamster brain is sensitive to cleavage by proteases. ${ }^{40}$ We therefore tested whether the duration of sample storage affected WBC-associated $\operatorname{PrP}^{\mathrm{C}}$. Using a panel of anti-PrP Fab fragments recognizing different linear epitopes along the PrP polypeptide, we monitored changes in the levels of $\mathrm{PrP}^{\mathrm{C}}$ on the surface of WBCs, as processed human buffy coats were allowed to age at $4^{\circ} \mathrm{C}$ (Figure 1c). In fresh samples less than $24 \mathrm{~h}$ old, each anti-PrP Fab registered a different maximum staining capacity, which we normalized to $100 \%$ for comparison. With samples stored for 2 days, antibody binding was specifically reduced for Fab fragments E123 and E149 that target the $\mathrm{N}$ terminus of $\mathrm{PrP}^{\mathrm{C}}$ (Figure 1c), indicating that $\mathrm{WBC}$-associated $\operatorname{PrP}^{\mathrm{C}}$ molecules were subjected to limited proteolysis. When experiments were performed in the presence of protease inhibitors, Fabs E123 and E149 showed increased binding to the aged samples. Because sample storage seemed to affect antibody detection of $\operatorname{PrP}^{\mathrm{C}}$, all specimens were analyzed immediately after processing and only fresh human peripheral WBCs less than $24 \mathrm{~h}$ old were used.

To study the influence of cell differentiation, we used QIFIKIT calibration beads (Dako) in conjunction with six different WBC surface markers to quantify the number of cell-associated $\mathrm{PrP}^{\mathrm{C}}$ molecules in four human buffy coats (Figure 2a). Of the three types of $\mathrm{CD}^{+} \mathrm{T}$ cells (T4),

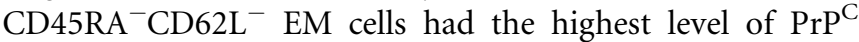
expression (12854 \pm 1695$)$, followed by $\mathrm{CD}_{45 \mathrm{RA}^{-}}$ $\mathrm{CD} 2 \mathrm{~L}^{+} \mathrm{CD} 27^{+}$central memory $(\mathrm{CM})$ cells $(7867 \pm 287)$ and $\mathrm{CD} 45 \mathrm{RA}^{+} \mathrm{CD} 2 \mathrm{~L}^{+} \mathrm{CD} 27^{+}$naive $(\mathrm{N})$ cells $(4944 \pm 589)$. The differences in $\operatorname{PrP}^{\mathrm{C}}$ levels were statistically significant between all three sets of $\mathrm{T} 4$ cells $(\mathrm{N} v s \mathrm{CM}, P=0.01 ; \mathrm{N}$ vs $\mathrm{EM}, P=0.004$; CM $v s$ EM, $P=0.04$; Figure $2 \mathrm{~b}$ ). Because the relative abundance of these $\mathrm{T}$-cell populations can change dramatically during viral infections, a patient's immunological status can modulate the levels of $\operatorname{PrP}^{\mathrm{C}}$ molecules in circulation.

\section{Surface PrP on WBCs and Platelets}

We determined whether the amount of total surface $\operatorname{PrP}^{\mathrm{C}}$ on WBC differs in patients with sCJD compared to healthy donors, using quantitative FACS analysis. Fresh buffy coats from patients with sCJD, age-matched controls with other neurological diseases and anonymous healthy blood donors (Table 1) were stained in duplicate with anti-PrP antibody 6H4 and IgG1 isotype control, along with a series of calibration beads from the QIFIKIT kit (Dako). To obtain the 

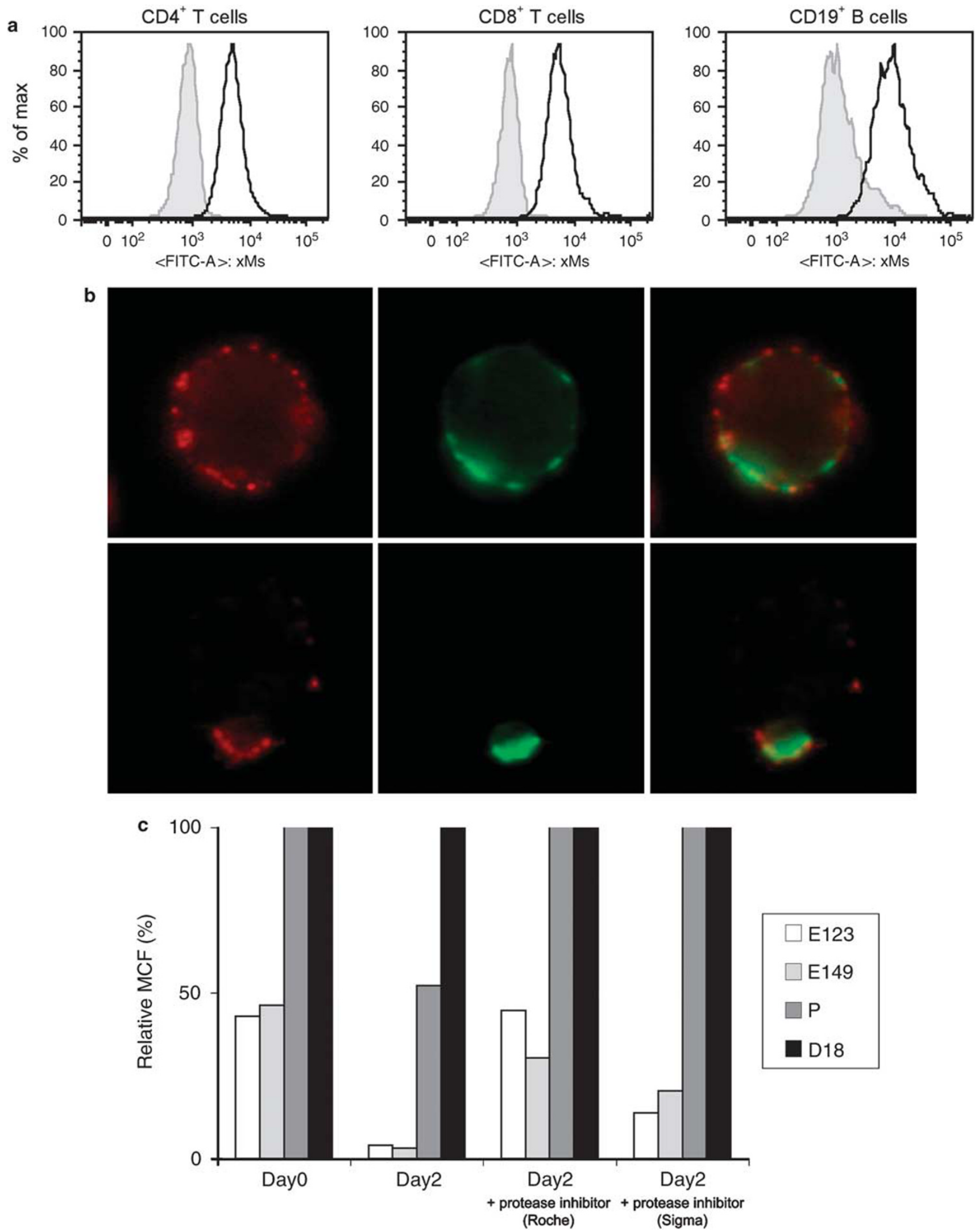

\section{$\square \mathrm{E} 123$ \\ $\square \mathrm{E} 149$ \\ $\square \mathrm{P}$ \\ D18}


number of $\operatorname{PrP}^{\mathrm{C}}$ molecules per cell, we subtracted the number of bound isotype control antibody from the number of bound $6 \mathrm{H} 4$. To identify different WBC populations, we also labeled buffy coats with a combination of cell markers: $\mathrm{CD} 3{ }^{+} \mathrm{CD} 4{ }^{+} \mathrm{CD}^{-}$for $\mathrm{CD} 4 \mathrm{~T}$ cells, $\mathrm{CD} 3{ }^{+} \mathrm{CD} 8{ }^{+} \mathrm{CD} 4^{-}$for $\mathrm{CD} 8 \mathrm{~T}$ cells, $\mathrm{CD}^{-} \mathrm{CD}^{-} 6^{+} \mathrm{CD} 4^{-}$for $\mathrm{NK}$ cells, and $\mathrm{CD} 41^{+} \mathrm{CD} 61^{+}$for platelets. All of the three types of lymphocytes expressed between 5000 and $10000 \mathrm{PrP}^{\mathrm{C}}$ molecules on their surfaces, whereas only low levels of $\mathrm{PrP}^{\mathrm{C}}$ were found on platelets (Figure 3). It is notable that a small fraction of platelets $(<14 \%)$ was found to express high levels of $\mathrm{PrP}^{\mathrm{C}}$ $(172806 \pm 25504 \quad(n=10)$; data not shown). Because the significance of these novel, high- $\mathrm{PrP}^{\mathrm{C}}$-expressing platelets is unknown and their frequency varied widely among samples, they were excluded from further analysis. The patients with sCJD expressed less $\mathrm{PrP}^{\mathrm{C}}$ on their platelets than healthy donors $(P=0.05)$, as did age-matched, neurological controls $(P=0.02)$. No significant differences were found between patients with sCJD and neurological controls in any of the WBC populations tested (Figure 3 ).

To verify the differential expression of $\operatorname{PrP}^{\mathrm{C}}$ on lymphocytes and platelets, we sorted by FACS six different cell types from five healthy donors and quantified their total $\operatorname{PrP}^{\mathrm{C}}$ content using the CDI (Figure 4). One million cells per specimen were assayed for all cell types, except platelets, which were tested at four different concentrations. $\mathrm{CD} 4^{+}$and $\mathrm{CD} 8^{+} \mathrm{T}$ lymphocytes expressed more $\mathrm{PrP}^{\mathrm{C}}$ per cell than platelets, which showed a $\operatorname{PrP}^{\mathrm{C}}$ expression level similar to that of $\mathrm{B}$ cells, granulocytes, and monocytes (Figure 4). Nonetheless, the majority of cell-associated $\operatorname{PrP}^{\mathrm{C}}$ is attributed to the platelet fraction because of the overwhelming abundance of platelets in circulation compared to other WBC fractions.

\section{WBC Profile of Patients with SCJD}

We next examined the composition of circulating WBCs in patients with SCJD. Five to eight fresh whole blood samples were collected per control and patient group, and analyzed with TruCOUNT beads (BD Biosciences) and WBC markers (Table 2). As expected, platelets were the most abundant cell species in peripheral blood, followed by granulocytes and monocytes. In six of seven subtypes tested, the frequencies of circulating WBCs were similar for all three patient groups. Granulocytes were more abundant in sCJD samples compared to healthy donors ( $P=0.07$; Figure 5$)$. However, due to considerable overlap between the data sets from patients with sCJD and neurological controls, sCJD cases could not be distinguished by their elevated granulocyte count alone. The blood of patients with sCJD also contained more $\mathrm{CD} 41^{+} \mathrm{CD} 61^{+}$platelets than samples from both healthy donors and neurological controls (Table 2). These trends, however, were not statistically significant until outliers were omitted from the analysis $(P=0.06,0.08)$.

\section{Further Fractionation of WBCs}

We fractionated all major WBC subpopulations from healthy donors, neurological controls, and symptomatic patients with sCJD. Purified cells were then frozen in aliquots until subsequent CDI testing.

First, we concentrated whole blood samples by centrifugation and isolated the most abundant nucleated WBCs in circulation, namely granulocytes, monocytes, $\mathrm{CD} 4{ }^{+} \mathrm{T}$ cells, and B cells (Supplementary Figure S1). This group of target cells possesses a diverse range of biological and physical characteristics, such as function, half-life in circulation, and trafficking. Using two scattering parameters and surface markers CD4 and CD19, we successfully sorted these cells to $>95 \%$ purity (Supplementary Figure S1). Next, B cells, $\mathrm{CD}^{+} \mathrm{T}$ cells, NK cells, and $\gamma \delta \mathrm{T}$ cells were isolated (Supplementary Figure S2). Being relatively rare in blood, these lymphocytes normally have a circulating frequency between 1 and $0.1 \%$, which could limit our sorting efficiency. Therefore, we enriched samples for lymphocytes before FACS sorting, by processing the whole blood samples into buffy coats using Percoll gradient centrifugation. The WBCs were then fractionated in a five-color sorting scheme, using surface markers CD3, CD8, CD19, CD56, and $\gamma \delta \mathrm{TCR}$, as well as physical parameters (Supplementary Figure S2). An average purity of $>95 \%$ was achieved for B cells, CD8 ${ }^{+} \mathrm{T}$ cells, and NK cells. Nonclassical $\gamma \delta$ T cells were only enriched to $\sim 70 \%$, possibly due to their extremely low starting frequency as well as to variability in the labeling of the $\gamma \delta \mathrm{TCR}$ marker. Finally, platelets were isolated using CD61 MACS beads (Miltenyi Biotec) and the AutoMACS system (Miltenyi Biotec) (Supplementary Figure S3).

\section{Detection of PrP ${ }^{\mathrm{Sc}}$ in WBCs and Platelets}

To measure the concentration of $\operatorname{PrP}^{\mathrm{Sc}}$ in WBCs using the $\mathrm{CDI}$, we assayed samples in duplicate using two different Europium-labeled antibodies, 3F4 and HuM-P, for detection. Sorted $\mathrm{CD} 4{ }^{+} \mathrm{T}$ cells, B cells, monocytes, and granulocytes from five subjects in each patient group were pooled and tested initially by the standard CDI protocol. We found no

Figure 1 Surface expression of $\mathrm{PrP}^{C}$ on human peripheral white blood cells (WBCs). (a) FACS analysis of anti-PrP ${ }^{C}$ antibody $3 F 4$ staining on CD4 ${ }^{+} \mathrm{T}$ cells (left), $\mathrm{CD}^{+} \mathrm{T}$ cells (middle), and CD19 ${ }^{+} \mathrm{B}$ cells (right). Staining with 3F4 is shown as a solid black line, with lgG2a isotype control shown in gray. (b) Distribution of surface PrPC (red) and CD56/N-CAM (green) molecules on NK cells. On the majority of NK cells, PrPC had a punctate expression pattern that did not correspond to that of CD56. However, $\operatorname{PrP}^{C}$ and CD56 colocalized in polarized cells (right panels). (c) N-terminal proteolysis of surface PrP on WBCs. Fresh buffy coats were resuspended in RPMI-1640 medium in the presence or absence of protease inhibitor cocktails for 2 days. The integrity of cell-associated PrPC molecules was then probed with a panel of anti-PrP Fab fragments, including E123 and E149 that bind to the N-terminal portion of the PrP molecule. Results shown are representative of two independent experiments. 

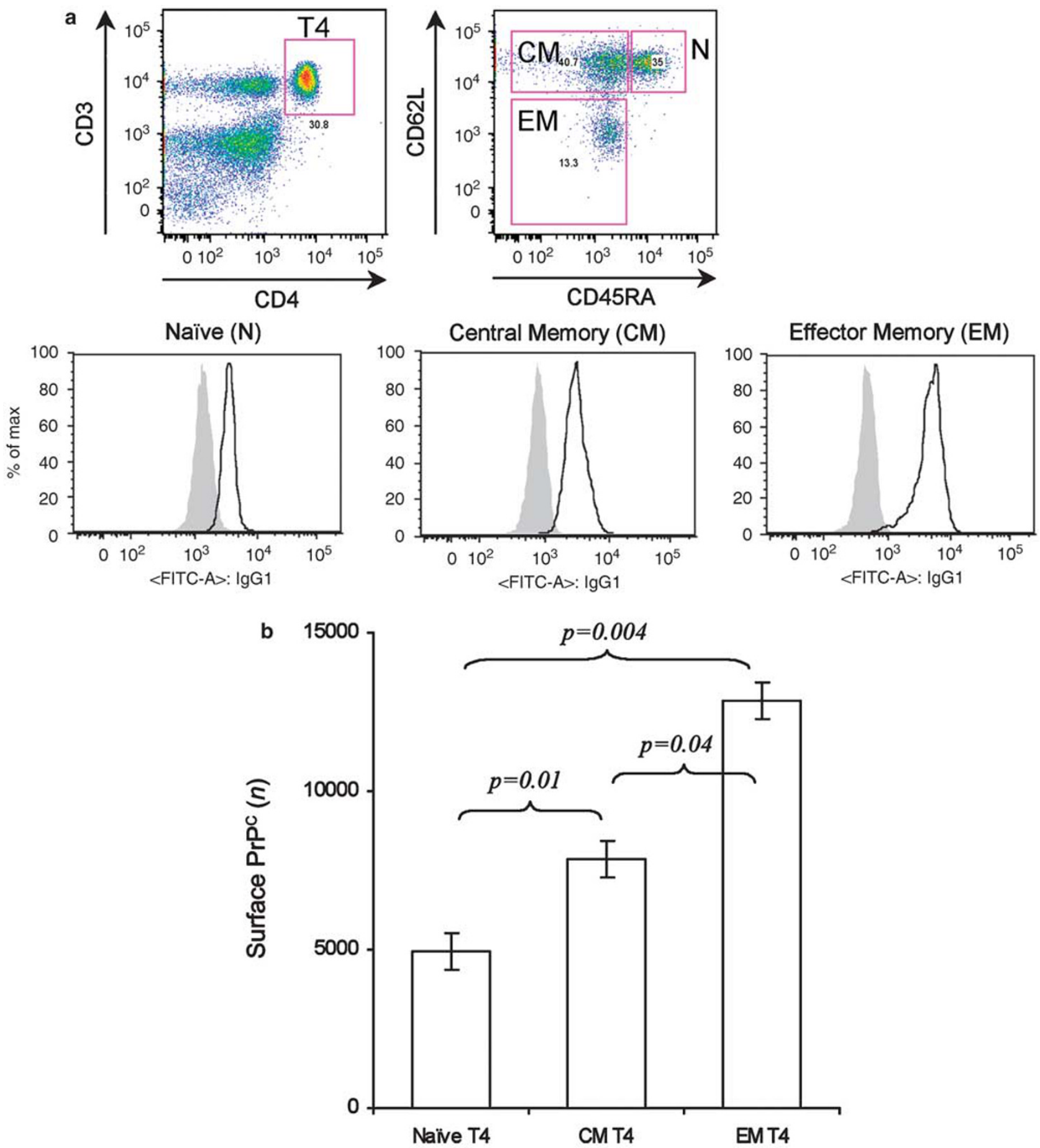

Figure 2 Surface expression of $\operatorname{PrP}^{\mathrm{C}}$ on peripheral $\mathrm{CD} 4^{+} \mathrm{T}$ cells at different stages of differentiation. (a) Upon six-color $\mathrm{FACS}$ analysis, $\mathrm{CD}^{+} \mathrm{CD}^{+}{ }^{+} \mathrm{T}^{\mathrm{c}}$ cells

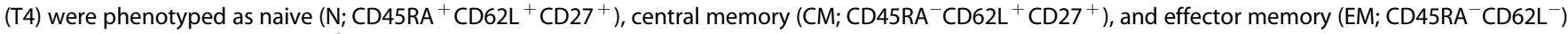
cells. FACS staining with anti-PrPC Fab fragment $6 \mathrm{H} 4$ is shown as a solid black line, with isotype lgG1 control in gray. (b) Histograms show that both types of antigen-experienced T4 cells expressed significantly higher levels of surface PrPC than N T4 cells. The difference between EM and N cells was more than twofold. $P$-values were determined by Student's $t$-test. Specimens from at least four donors were used in this analysis. All samples were tested in duplicate.

positive $\mathrm{PrP}^{\mathrm{Sc}}$ signals in these WBC populations (data not shown). Similarly, repeating this experiment using 10 times as many cells per sample generated no $\operatorname{PrP}^{\mathrm{Sc}}$ signal above background. After subsequent optimization, we tested B cells, granulocytes, NK cells, platelets, $\mathrm{CD}^{+}{ }^{+}$cells, and $\gamma \delta \mathrm{TCR}$ T cells purified from individual patient samples; $\sim 10$ specimens from each group were used (Figure 6). The optimized CDI was able to detect $\operatorname{PrP}^{\mathrm{Sc}}$ in $\operatorname{Prnp}^{0 / 0}$ brain homogenate spiked with 

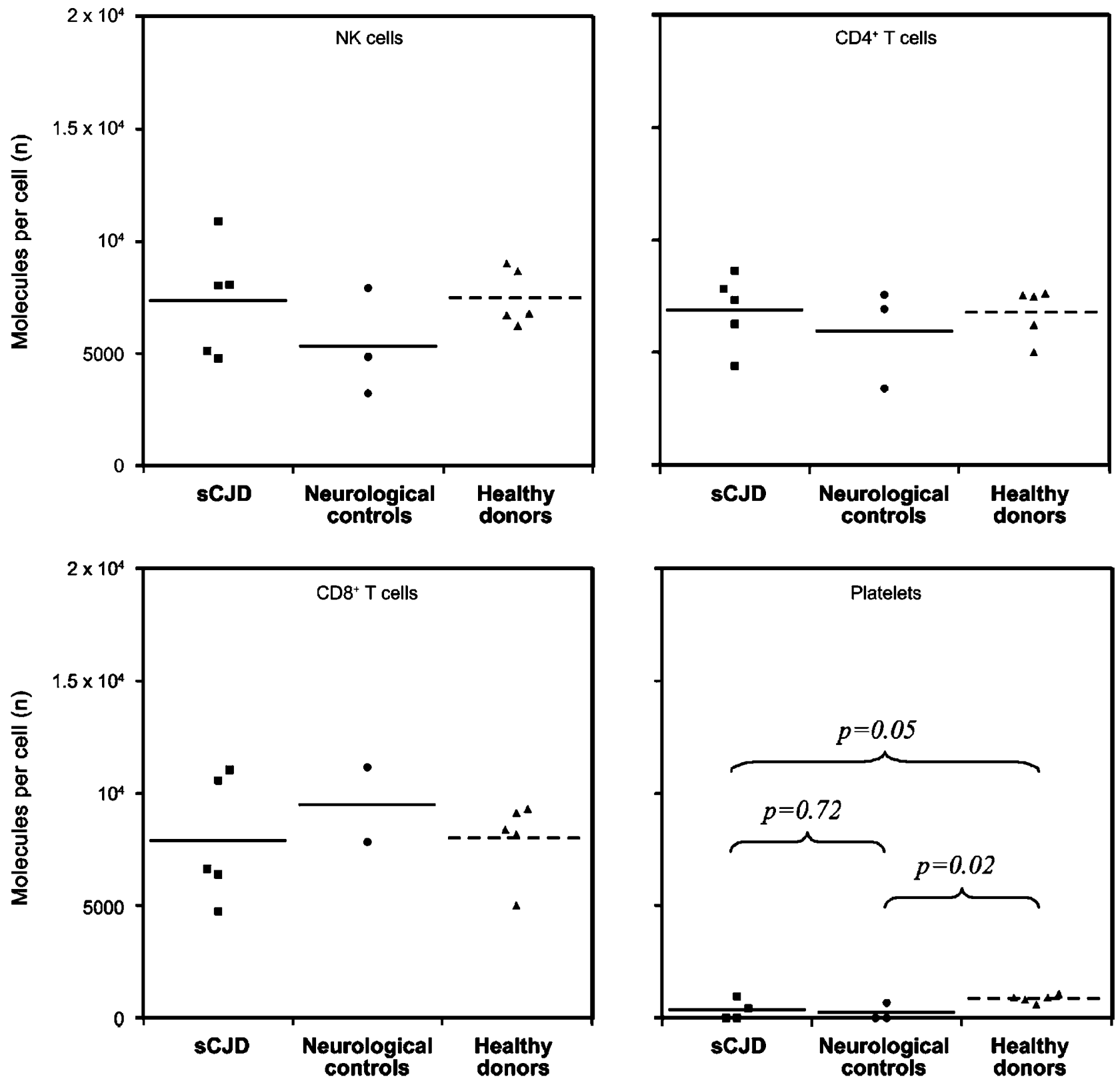

Figure 3 Surface PrP ${ }^{C}$ expression on circulating WBCs was similar in patients with SCJD and neurological controls. Quantification of surface PrP molecules on circulating WBC subpopulations by quantitative FACS. Freshly prepared buffy coats were stained with anti-PrP antibody $6 \mathrm{H} 4$ and analyzed with QIFIKIT (Dako) reagent. Negative control samples were concomitantly stained with isotype control lgG1 antibody. The absolute number of surface PrP molecules per cell was obtained by subtracting the background value from the total number of bound $6 \mathrm{H} 4$ molecules. The $\mathrm{CD} 41^{+} \mathrm{CD} 61^{+}$platelets in our specimens produced two distinct populations of $\operatorname{PrP}^{C}$ expression; only the predominant platelet population expressing low levels of $\operatorname{Pr} P^{C}$ was included in this analysis. The statistical differences in $\operatorname{PrP}^{C}$ expression between patients with $\mathrm{SCJD}$, neurological controls, and healthy donors were calculated by Student's $t$-test. Mean numbers of $\operatorname{PrP}^{C}$ molecules per cell, for each patient group and each WBC subpopulation, are indicated by the horizontal lines. Each data point represents a unique patient. All samples were tested in duplicate.

$0.05 \%$ sCJD brain homogenate over a 10000 -fold range of brain homogenate concentrations. The detection limit of recHuPrP(90-231) was $0.5 \mathrm{pg} / \mathrm{ml}$, equivalent to $\sim 6$ attomoles per plate well. The CDI signal and calculated concentrations of $\mathrm{PrP}^{\mathrm{Sc}}$ fluctuate in all groups around the detection limit of the CDI. None of the purified WBC fractions from patients with sCJD exceeded the background levels of donor or neurological control groups (Figure 6). Cell densities per sample were as follows: $5 \times 10^{5}$ B cells, $10^{6}$ granulocytes, $5 \times 10^{5} \mathrm{NK}$ cells, $3 \times 10^{7}$ platelets, $5 \times 10^{5} \mathrm{CD}^{+} \mathrm{T}$ cells, $5 \times 10^{5} \mathrm{CD}^{+} \mathrm{T}$ cells, and $5 \times 10^{5}$ monocytes. 


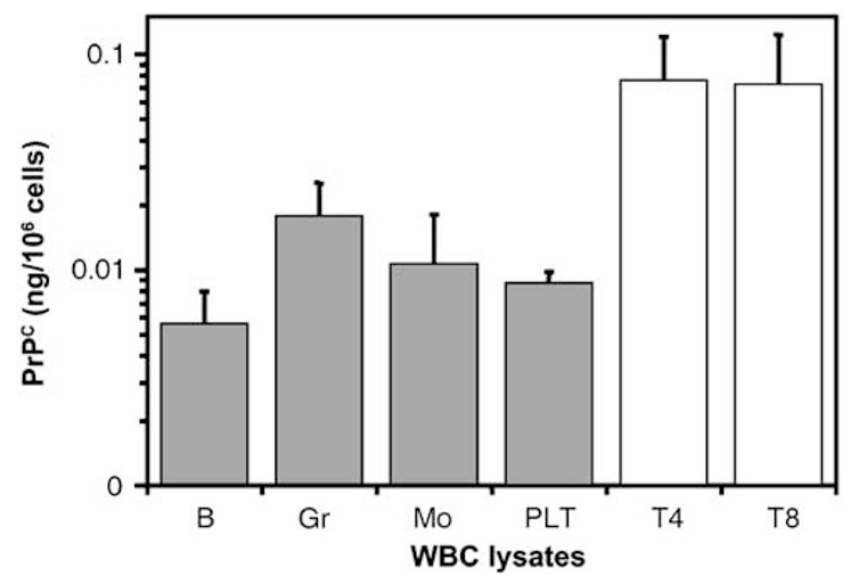

Figure $4 \mathrm{~T} 4$ and T8 cells express more $\operatorname{PrP}^{C}$ than the other cell subtypes. Concentration of PrPC in FACS-sorted peripheral WBCs from five healthy donors was compared by sandwich CDI. B cells (B), granulocytes (Gr), monocytes (Mo), platelets (PLT), CD4 ${ }^{+} \mathrm{T}_{\text {cells }}(\mathrm{T} 4)$, and $\mathrm{CD} 8{ }^{+} \mathrm{T}$ cells (T8). All samples were tested in duplicate using MAR1 antibody for capture, $0.1 \mu \mathrm{g} /$ $\mathrm{ml}$ of Europium-labeled 3F4 antibody for detection, and recHuPrP(90-231) as a calibrant. Platelets were assayed at four different concentrations.

Table 2 Relative abundance of WBC components of fresh whole blood from patients with SCJD and controls

\begin{tabular}{lccc}
\hline WBC component & Healthy donors & Neurologic controls & SCJD \\
\cline { 2 - 4 } & \multicolumn{3}{c}{ (million/ml \pm s.e.m.) } \\
\hline Gr & $2.13 \pm 0.24$ & $3.83 \pm 0.30$ & $5.49 \pm 1.88$ \\
T4 & $0.52 \pm 0.13$ & $0.98 \pm 0.18$ & $0.77 \pm 0.16$ \\
T8 & $0.25 \pm 0.04$ & $0.34 \pm 0.06$ & $0.31 \pm 0.09$ \\
B & $0.26 \pm 0.09$ & $0.18 \pm 0.04$ & $0.22 \pm 0.04$ \\
NK & $0.30 \pm 0.06$ & $0.52 \pm 0.13$ & $0.41 \pm 0.05$ \\
Mo & $0.45 \pm 0.06$ & $0.50 \pm 0.05$ & $0.60 \pm 0.10$ \\
PLT & $143 \pm 12$ & $138 \pm 20$ & $221 \pm 42$
\end{tabular}

B, B cells; Gr, granulocytes; Mo, monocytes; NK, natural killer; PLT, platelets; T4, $\mathrm{CD}^{+}{ }^{\mathrm{T}}$ cells; $\mathrm{T} 8, \mathrm{CD} 8^{+} \mathrm{T}$ cells.

Each patient group consisted of 5-8 individuals. All samples were tested in duplicate.

${ }^{\mathrm{a}}$ Platelets were gated on $\mathrm{CD} 41^{+} \mathrm{CD} 61^{+}$double-positive subpopulation.

\section{DISCUSSION}

In studies described here, we found that $\mathrm{PrP}^{\mathrm{C}}$ is widely distributed among subpopulations of circulating WBCs. We determined that the highest levels of $\operatorname{PrP}^{\mathrm{C}}$ were found in a subpopulation of $\mathrm{T}$ lymphocytes: $\sim 12000 \mathrm{PrP}^{\mathrm{C}}$ molecules were found per $\mathrm{CD} 4{ }^{+} \mathrm{CD} 45 \mathrm{RA}^{-} \mathrm{CD} 62 \mathrm{~L}^{-} \mathrm{EM} \mathrm{T}$ helper cell. Although platelets expressed low levels of $\mathrm{PrP}^{\mathrm{C}}$ on their surface, their high abundance in circulation resulted in the majority of $\operatorname{PrP}^{\mathrm{C}}$ being platelet associated.

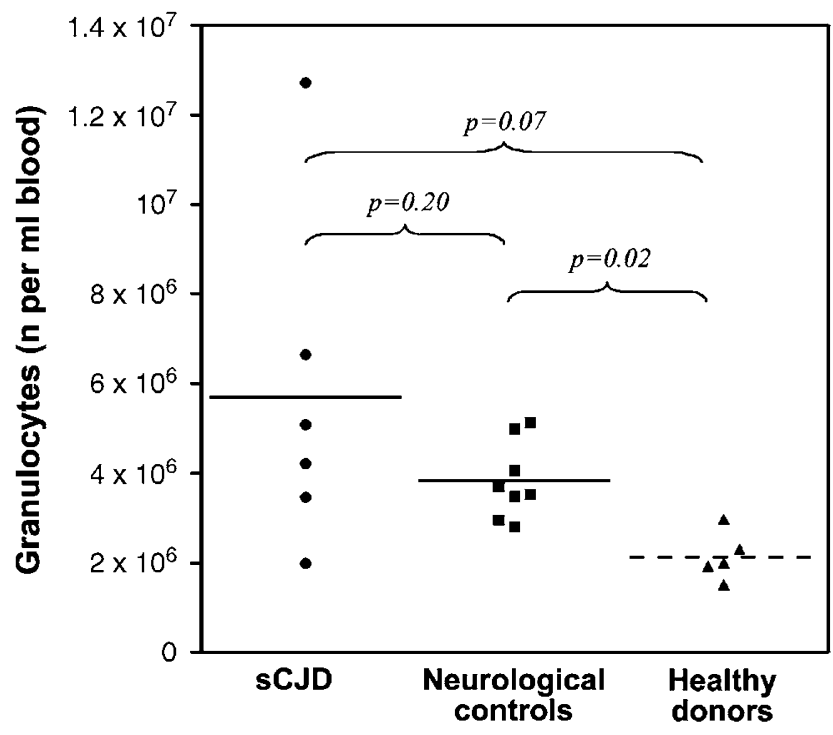

Figure 5 Levels of circulating granulocytes in patients with SCJD (circles), neurological controls (squares), and healthy donors (triangles). Each symbol represents an individual sample and the average of each group is indicated by a horizontal line. Each group consisted of five to eight patient samples. All specimens were tested in duplicate. $P$-values were calculated by Student's $t$-test.

The presence of $\operatorname{PrP}^{\mathrm{C}}$ on the surface of peripheral blood cells has been reported previously. ${ }^{12,35,41,42}$ In fact, $\operatorname{PrP}^{\mathrm{C}}$ is also known as CD230, according to the immunological nomenclature of cluster differentiation markers. ${ }^{43}$ Nonetheless, more than 20 years after the discovery of $\operatorname{PrP}^{\mathrm{C}}$, its biological function remains unclear. The coexpression of $\mathrm{PrP}^{\mathrm{C}}$ and $\mathrm{N}$ CAM as well as their likely physical interactions on the surface of neurons suggests a function in signal transduction. ${ }^{36-}$ ${ }^{39}$ This is consistent with our finding that these two proteins colocalize in polarized NK cells (Figure $1 \mathrm{~b}$ ). On the physiological level, the elevated expression of $\mathrm{PrP}^{\mathrm{C}}$ on EM $\mathrm{T}$ cells compared to $\mathrm{CM} \mathrm{T}$ cells and naive T cells (Figure 2) suggests an involvement in WBC homing and/or extravasation, which has recently been demonstrated in vitro for monocytes. ${ }^{44}$

In contrast to an earlier report, ${ }^{45}$ we were able to detect low levels of $\mathrm{PrP}^{\mathrm{C}}$ expression using the sandwich $\mathrm{CDI}$ on purified granulocytes, monocytes, CD4 ${ }^{+} \mathrm{T}$ cells, $\mathrm{CD} 8{ }^{+} \mathrm{T}$ cells, B cells, and platelets (Figure 4). This ubiquitous expression of $\operatorname{PrP}^{\mathrm{C}}$ on circulating human WBCs contrasts with our observations in wild-type, inbred FVB and CD-1 mice. Using a panel of seven anti-PrP Fab fragments, we were able to detect surface expression of mouse $\operatorname{PrP}^{\mathrm{C}}$ on LPS-stimulated splenocytes, bone marrow-derived dendritic cells and mast cells, but not on circulating $\mathrm{CD} 4{ }^{+} \mathrm{T}$ cells, $\mathrm{CD} 8{ }^{+} \mathrm{T}$ cells, NK cells, B cells, monocytes, or granulocytes (data not shown). However, transgenic mice overexpressing truncated $\operatorname{PrP}^{\mathrm{C}}$, denoted $\mathrm{Tg} 9949$ mice, have readily detectable $\mathrm{PrP}^{\mathrm{C}}$ on their peripheral lymphocytes (data not shown). Because lymphocytes upregulate $\operatorname{PrP}^{\mathrm{C}}$ upon activation, the lack of 

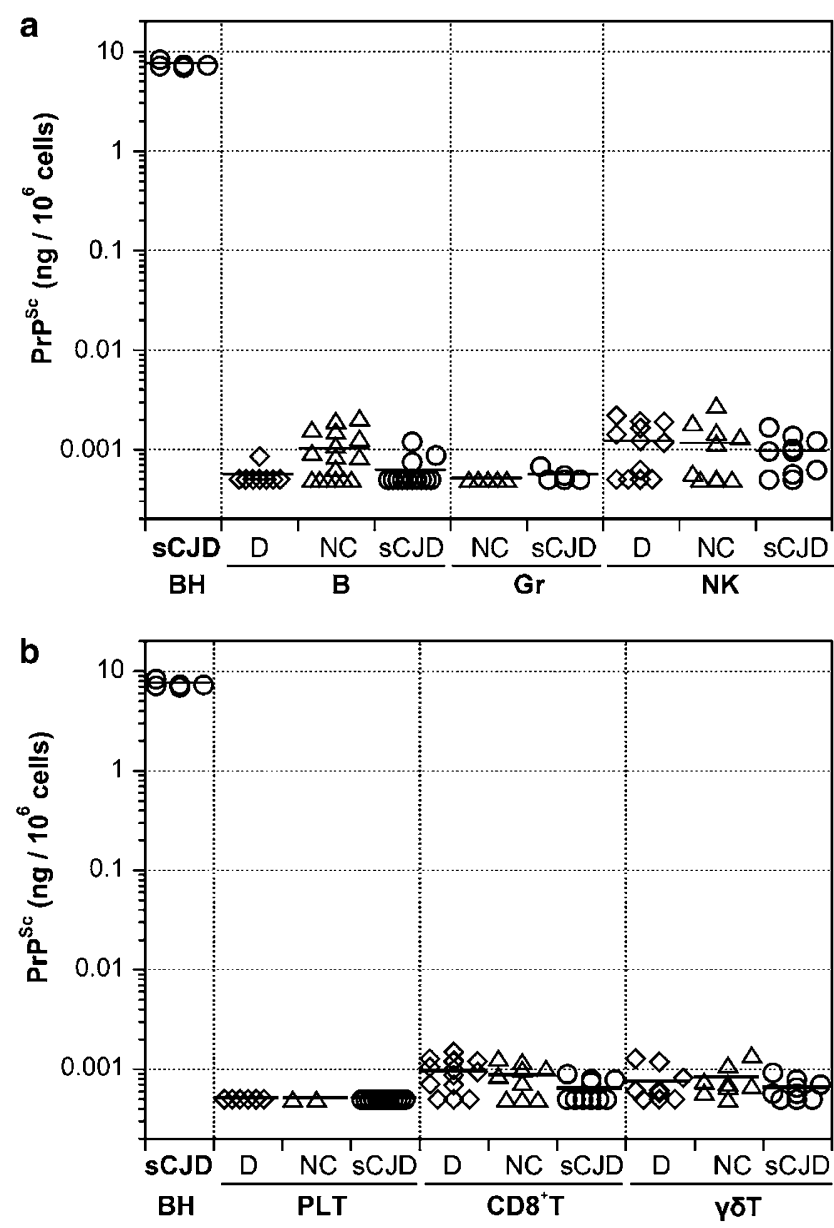

Figure $6 \mathrm{CDI}$ testing for $\mathrm{PrP}^{\mathrm{Sc}}$ in individual patient samples. Sorted cell subtypes from patients with SCJD (circles), healthy donors (diamonds), and neurological controls (triangles) were assayed in the CDI for the presence of $\mathrm{PrP}^{\mathrm{Sc}}$. Results were similar for all samples in all patient groups. Number of cells per specimen: (a) $5 \times 10^{5}$ B cells (B), $1 \times 10^{6}$ granulocytes (Gr), $5 \times 10^{5}$ NK cells (NK), (b) $3 \times 10^{7}$ platelets (PLT), $5 \times 10^{5} \mathrm{CD}^{+} \mathrm{T}$ cells, and $2 \times 10^{5}$ nonclassical $\gamma \delta$ T cells. Similar results were obtained using $3 \times 10^{8}$ platelets, $5 \times 10^{5}$ monocytes, and $5 \times 10^{5} \mathrm{CD}^{+}{ }^{+} \mathrm{T}$ cells (data not shown). Each symbol represents the measurement from an individual sample; the horizontal line indicates the mean level for each group and cell type. All specimens were assayed in duplicate. B cells, platelets, and nonclassical $\gamma \delta \mathrm{T}$ cells were tested twice. Each plate contained serial dilutions of recHuPrP $(90-231)$ and SCJD brain homogenate $(\mathrm{BH})$ diluted to $0.05 \%(\mathrm{w} / \mathrm{v})$ as a positive control.

surface $\operatorname{PrP}^{\mathrm{C}}$ in peripheral WBCs in wild-type mice is likely to reflect the naive immunological status of these captive laboratory animals. Similarly, we found fewer $\mathrm{PrP}^{\mathrm{C}}$ molecules on the cell surface of circulating naive $\mathrm{T}$ cells compared to memory $\mathrm{T}$ cells in human blood (Figure 3 ).

Mononucleated WBCs such as T cells and NK cells generally express at least 10 times more $\operatorname{PrP}^{\mathrm{C}}$ than platelets, as determined by quantitative FACS (Figure 3 ) and the CDI (Figure 4). This observation is consistent with a previous study that used a direct FITC conjugate of the anti-PrP antibody, $6 \mathrm{H} 4 .{ }^{42}$ Others using the same QIFIKIT reagent for quantitative FACS obtained slightly different results, which could be due to their use of another anti-PrP antibody (3F4) and/or unstained samples as negative controls. ${ }^{35}$

\section{PrP Expression in Patients with sCJD}

Using quantitative FACS analysis, we found that neither WBC composition nor the amount of cell-surface $\mathrm{PrP}^{\mathrm{C}}$ molecules was altered in patients with sCJD. Eight different WBC fractions types from the peripheral blood of patients with sCJD were assessed for $\operatorname{PrP}^{\mathrm{Sc}}$. We were unable to find any evidence for $\mathrm{PrP}^{\mathrm{Sc}}$ in purified granulocytes, monocytes, B cells, CD $4^{+} \mathrm{T}$ cells, $\mathrm{CD} 8^{+} \mathrm{T}$ cells, NK cells, nonclassical $\gamma \delta$ $\mathrm{T}$ cells, or platelets.

Although we observed slightly lower levels of PrP on the platelets of patients with sCJD and neurological controls compared to healthy donors $(P=0.02$ and 0.05 , respectively; Figure 3$),{ }^{45,46}$ we hesitate to assign importance to this finding for several reasons. First, our sample size was small $(n=3-5)$ and second, the differences were only statistically significant after a small subpopulation of platelets with an uncharacteristically high level of $\operatorname{PrP}(172806 \pm 25504)$ was excluded from the analysis (data not shown). Third, because platelet PrP was reduced in both patients with sCJD and neurological controls, it cannot be used as a specific biological marker for prion disease. In half of our patients with $\mathrm{sCJD}$, the frequency of circulating granulocytes was increased compared to healthy donors $(P=0.07$; Table 2, Figure 5). This finding might be a consequence of secondary infections that often occur in debilitated patients.

Eight subpopulations of WBCs were purified from the peripheral blood of over 100 individuals. We were unable to detect $\mathrm{PrP}^{\mathrm{Sc}}$ in platelets, $\mathrm{NK}$ cells, $\mathrm{CD} 8^{+}{ }^{\mathrm{T}}$ cells, $\mathrm{CD} 4^{+} \mathrm{T}$ cells, $\mathrm{B}$ cells, monocytes, or granulocytes, using the CDI. The concentration of $\mathrm{PrP}^{\mathrm{Sc}}$ in $0.05 \%$ sCJD brain homogenate measured by CDI is $\sim 7 \mathrm{ng} / \mathrm{ml}$ (Figure 6), with a detection limit of $\sim 0.5 \mathrm{pg} / \mathrm{ml}$. Because the concentration of prions in $0.05 \%$ sCJD BH is $10^{3.0}-10^{4.3} \mathrm{IU} / \mathrm{ml}^{27}$, we estimate that the limit of prion detection in this CDI protocol is $\sim 1.4 \mathrm{IU} / \mathrm{ml}$ or less. Thus, our negative findings are consistent with the inability of retrospective epidemiological investigations to identify sCJD cases associated with blood transfusions. ${ }^{47}$ Importantly, leukodepletion in experimental scrapie studies did not completely eliminate prion infectivity in blood ${ }^{48}$ and transfusions of blood from sheep with scrapie or from deer with CWD efficiently transmitted disease to recipient animals. ${ }^{49-51}$ The high-affinity binding of $\mathrm{PrP}^{\mathrm{Sc}}$ to $\mathrm{LDLs}^{24}$ raised the possibility that prions in human blood are primarily found in the plasma fraction. Whether low levels of prions can be detected in the plasma lipoproteins of patients with sCJD using CDI and bioassay in mice expressing chimeric $\mathrm{Hu} / \mathrm{Mo}$ PrP transgenes ${ }^{52}$ remains to be determined (J Safar and SB Prusiner, in preparation).

Supplementary Information accompanies the paper on the Laboratory Investigation website (http://www.laboratoryinvestigation.org) 


\section{ACKNOWLEDGEMENTS}

We thank Chris Roden and Kristen Schardein-Fox for their technical assistance; Ingrid Schmid (UCLA), Marty Bigos (The Gladstone Institute), and all the flow cytometry engineers, especially Romulo Castrence (BD), for their assistance in the installation and maintenance of our BSL3 FACS Aria within a biosafety hood; the National Prion Disease Surveillance Center for PRNP sequencing; and to Hang Nguyen for her skillful editorial assistance. This work was supported by NIH grants AG02132, AG10770, AG021989, and RR024131; an NIH NINDS contract; and US Department of Defense contract.

1. Masters CL, Harris JO, Gajdusek DC, et al. Creutzfeldt-Jakob disease: patterns of worldwide occurrence and the significance of familial and sporadic clustering. Ann Neurol 1979;5:177-188.

2. Will RG, Alpers MP, Dormont $D$, et al. Infectious and sporadic prion diseases. In: Prusiner SB (ed). Prion Biology and Diseases, 2nd edn. Cold Spring Harbor Laboratory Press: Cold Spring Harbor, 2004, pp 629-671.

3. Bolton DC, McKinley MP, Prusiner SB. Identification of a protein that purifies with the scrapie prion. Science 1982;218:1309-1311.

4. Prusiner SB. Novel proteinaceous infectious particles cause scrapie. Science 1982;216:136-144.

5. Hsiao K, Baker HF, Crow TJ, et al. Linkage of a prion protein missense variant to Gerstmann-Sträussler syndrome. Nature 1989;338: 342-345.

6. Owen $F$, Poulter $M$, Lofthouse $R$, et al. Insertion in prion protein gene in familial Creutzfeldt-Jakob disease. Lancet 1989;333:51-52.

7. Pan K-M, Baldwin M, Nguyen J, et al. Conversion of $\alpha$-helices into $\beta$ sheets features in the formation of the scrapie prion proteins. Proc Nat Acad Sci USA 1993;90:10962-10966.

8. Borchelt DR, Scott M, Taraboulos A, et al. Scrapie and cellular prion proteins differ in their kinetics of synthesis and topology in cultured cells. J Cell Biol 1990;110:743-752.

9. Ramasamy I, Law M, Collins $\mathrm{S}$, et al. Organ distribution of prion proteins in variant Creutzfeldt-Jakob disease. Lancet Infect Dis 2003;3:214-222.

10. Glatzel $\mathrm{M}$, Abela $\mathrm{E}$, Maissen $\mathrm{M}$, et al. Extraneural pathologic prion protein in sporadic Creutzfeldt-Jakob disease. N Engl J Med 2003;349:1812-1820.

11. Wadsworth JD, Joiner S, Hill AF, et al. Tissue distribution of protease resistant prion protein in variant Creutzfeldt-Jakob disease using a highly sensitive immunoblotting assay. Lancet 2001;358: 171-180.

12. Cashman NR, Loertscher R, Nalbantoglu J, et al. Cellular isoform of the scrapie agent protein participates in lymphocyte activation. Cell 1990;61:185-192.

13. Fraser $\mathrm{H}$, Brown KL, Stewart K, et al. Replication of scrapie in spleens of SCID mice follows reconstitution with wild-type mouse bone marrow. J Gen Virol 1996;77:1935-1940.

14. Blattler $\mathrm{T}$, Brandner $\mathrm{S}$, Raeber $\mathrm{AJ}$, et al. PrP-expressing tissue required for transfer of scrapie infectivity from spleen to brain. Nature 1997;389:69-73.

15. Brown KL, Stewart K, Ritchie DL, et al. Scrapie replication in lymphoid tissues depends on prion protein-expressing follicular dendritic cells. Nat Med 1999;5:1308-1312.

16. Brown P. Blood infectivity, processing and screening tests in transmissible spongiform encephalopathy. Vox Sang 2005;89: 63-70.

17. Brown $\mathrm{P}$, Cervenáková L, McShane LM, et al. Further studies of blood infectivity in an experimental model of transmissible spongiform encephalopathy, with an explanation of why blood components do not transmit Creutzfeldt-Jakob disease in humans. Transfusion 1999:39:1169-1178.

18. Cervenáková L, Yakovleva O, McKenzie C, et al. Similar levels of infectivity in the blood of mice infected with human-derived VCJD and GSS strains of transmissible spongiform encephalopathy. Transfusion 2003:43:1687-1694.

19. Llewelyn CA, Hewitt PE, Knight RS, et al. Possible transmission of variant Creutzfeldt-Jakob disease by blood transfusion. Lancet 2004;363:417-421.

20. Peden AH, Head MW, Ritchie DL, et al. Preclinical vCJD after blood transfusion in a PRNP codon 129 heterozygous patient. Lancet 2004;364:527-529.
21. Wroe SJ, Pal S, Siddique D, et al. Clinical presentation and pre-mortem diagnosis of variant Creutzfeldt-Jakob disease associated with blood transfusion: a case report. Lancet 2006;368:2061-2067.

22. Health Protection Agency. Variant CJD and plasma products. http:// www.hpa.org.uk/webw/HPAweb\&HPAwebStandard/HPAweb_C/ $1195733818681 ? \mathrm{p}=1225960597236,2009$.

23. Castilla J, Saa P, Soto C. Detection of prions in blood. Nat Med 2005; 11:982-985.

24. Safar JG, Wille $H$, Geschwind MD, et al. Human prions and plasma lipoproteins. Proc Natl Acad Sci USA 2006;103:11312-11317.

25. Safar J, Wille $\mathrm{H}$, Itri $\mathrm{V}$, et al. Eight prion strains have $\operatorname{PrP}^{\mathrm{SC}}$ molecules with different conformations. Nat Med 1998:4:1157-1165.

26. Safar JG, Scott M, Monaghan J, et al. Measuring prions causing bovine spongiform encephalopathy or chronic wasting disease by immunoassays and transgenic mice. Nat Biotechnol 2002;20: 1147-1150.

27. Safar JG, Geschwind MD, Deering $C$, et al. Diagnosis of human prion disease. Proc Natl Acad Sci USA 2005;102:3501-3506.

28. Oberyszyn AS. Method for visualizing aerosol contamination in flow sorters. Curr Protoc Cytom 2002;19:3.5.1-3.5.7.

29. Leclerc $E$, Peretz D, Ball $H$, et al. Conformation of $\operatorname{PrP}^{C}$ on the cell surface as probed by antibodies. J Mol Biol 2003;326:475-483.

30. Bellon A, Seyfert-Brandt W, Lang W, et al. Improved conformationdependent immunoassay: suitability for human prion detection with enhanced sensitivity. J Gen Virol 2003;84:1921-1925.

31. Kascsak RJ, Rubenstein R, Merz PA, et al. Mouse polyclonal and monoclonal antibody to scrapie-associated fibril proteins. J Virol 1987;61:3688-3693.

32. Mehlhorn I, Groth D, Stöckel J, et al. High-level expression and characterization of a purified 142-residue polypeptide of the prion protein. Biochemistry 1996;35:5528-5537.

33. Büeler $\mathrm{H}$, Aguzzi A, Sailer A, et al. Mice devoid of PrP are resistant to scrapie. Cell 1993;73:1339-1347.

34. Prusiner SB, Groth D, Serban A, et al. Ablation of the prion protein (PrP) gene in mice prevents scrapie and facilitates production of anti-PrP antibodies. Proc Natl Acad Sci USA 1993;90:10608-10612.

35. Barclay GR, Hope J, Birkett CR, et al. Distribution of cell-associated prion protein in normal adult blood determined by flow cytometry. $\mathrm{Br}$ J Haematol 1999;107:804-814.

36. Mouillet-Richard S, Ermonval M, Chebassier C, et al. Signal transduction through prion protein. Science 2000;289:1925-1928.

37. Schmitt-Ulms G, Legname G, Baldwin MA, et al. Binding of neural cell adhesion molecules (N-CAMs) to the cellular prion protein. J Mol Biol 2001;314:1209-1225.

38. Schneider B, Mutel V, Pietri M, et al. NADPH oxidase and extracellular regulated kinases $1 / 2$ are targets of prion protein signaling in neuronal and nonneuronal cells. Proc Natl Acad Sci USA 2003;100: 13326-13331.

39. Santuccione A, Sytnyk V, Leshchyns'ka I, et al. Prion protein recruits its neuronal receptor NCAM to lipid rafts to activate $\mathrm{p} 59^{\text {fyn }}$ and to enhance neurite outgrowth. J Cell Biol 2005;169:341-354.

40. Pan K-M, Stahl N, Prusiner SB. Purification and properties of the cellular prion protein from Syrian hamster brain. Protein Sci 1992;1: 1343-1352.

41. Perini $F$, Vidal $R$, Ghetti $B$, et al. $\operatorname{PrP}_{27-30}$ is a normal soluble prion protein fragment released by human platelets. Biochem Biophys Res Commun 1996;223:572-577.

42. Holada K, Vostal JG. Different levels of prion protein ( $\operatorname{PrP}^{\mathrm{C}}$ ) expression on hamster, mouse and human blood cells. Br J Haematol 2000;110:472-480.

43. Evans EJ, Hene L, Sparks LM, et al. The T cell surface-how well do we know it? Immunity 2003;19:213-223.

44. Viegas $\mathrm{P}$, Chaverot $\mathrm{N}$, Enslen $\mathrm{H}$, et al. Junctional expression of the prion protein PrPC by brain endothelial cells: a role in transendothelial migration of human monocytes. J Cell Sci 2006;119: 4634-4643.

45. Fagge $T$, Barclay GR, Macgregor I, et al. Variation in concentration of prion protein in the peripheral blood of patients with variant and sporadic Creutzfeldt-Jakob disease detected by dissociation enhanced lanthanide fluoroimmunoassay and flow cytometry. Transfusion 2005;45:504-513.

46. Volkel $\mathrm{D}$, Zimmermann $\mathrm{K}$, Zerr I, et al. Immunochemical determination of cellular prion protein in plasma from healthy subjects and 
patients with sporadic CJD or other neurologic diseases. Transfusion 2001;41:441-448.

47. Zou S, Fang CT, Schonberger LB. Transfusion transmission of human prion diseases. Transfus Med Rev 2008;22:58-69.

48. Gregori L, Gurgel PV, Lathrop JT, et al. Reduction in infectivity of endogenous transmissible spongiform encephalopathies present in blood by adsorption to selective affinity resins. Lancet $2006 ; 368$ : 2226-2230.

49. Hunter N, Foster J, Chong A, et al. Transmission of prion disease by blood transfusion. J Gen Virol 2002;83:2897-2905.
50. Mathiason CK, Powers JG, Dahmes SJ, et al. Infectious prions in the saliva and blood of deer with chronic wasting disease. Science 2006;314:133-136.

51. Houston F, McCutcheon S, Goldmann W, et al. Prion diseases are efficiently transmitted by blood transfusion in sheep. Blood 2008;112:4739-4745.

52. Korth C, Kaneko K, Groth D, et al. Abbreviated incubation times for human prions in mice expressing a chimeric mouse-human prion protein transgene. Proc Natl Acad Sci USA 2003;100: 4784-4789. 